\title{
A Qualitative Study on Environmental Factors Affecting Iranian Women Entrepreneurs' Growth Orientation
}

\author{
Zahra Arasti (Corresponding author) \\ Faculty of Entrepreneurship, University of Tehran \\ Tehran, Iran \\ Tel: +982-161-119-227Ｅ-mail: Arasti@ut.ac.ir \\ Sima Oliayee Rezayee \\ University of Tehran \\ Tehran, Iran
}

Tel: +982-188-997-903Ｅ-mail: s_rezayee@ut.ac.ir

Behrooz Zarei

Faculty of Entrepreneurship, University of Tehran

Tehran, Iran

Tel: +982-161-119-226 E-mail: bzarei@ut.ac.ir

Shirin Majd Shariat Panahi

Master Entrepreneurship Management student, University of Tehran

Tehran, Iran

Tel: +982-188-550-101Ｅ-mail: shirin_panahi@ut.ac.ir

Received: January 15, 2012

Accepted: February 22, $2012 \quad$ Published: April 15, 2012

doi: $10.5430 /$ jms.v3n2p39

URL: http://dx.doi.org/10.5430/jms.v3n2p39

\begin{abstract}
Despite the impressive growth in the number of firms run by women entrepreneurs, most of these businesses continue to remain small and women-owned firms have not grown as fast as male entrepreneurs. There are many reasons that may help explain the growth limitations in women-owned firms. Among all, growth orientation is an important factor. A common finding in entrepreneurship literature shows that ventures owned by women tend to be smaller than those by men are. This difference can be due to individual, organizational and environmental factors.

Since half of Iran's population is women who are more willing to have higher education and contribution in the society, they deal with more challenges rather than their male counterparts. So attention to the factors affecting growth orientation of their ventures is the same as deliberate economic development and national income. This is a qualitative study to identify environmental factors affecting growth orientation of women entrepreneurs. Data analysis of 10 semi-structured interviews on a sample of women entrepreneurs indicated environmental factors in three groups of "economic", "socio-cultural" and "legal" factors.
\end{abstract}

Keywords: Business Growth, Growth Orientation, Women Entrepreneurs, Environmental Factors, Qualitative Study, Iran

\section{Introduction}

Women's economic activities empower them economically and enable them overall, to contribute more to the development of their country. Recognizing this value and its importance, many governments in the world are paying at least some attention in order to create an environment conducive for the establishment of women-owned enterprises 
(Buttner, 1993, Verheul et al., 2006, Kickul et al, 2007, Roomi et al., 2009).

In $2008,18.7 \%$ of workers 18 to 64 were either an owner/manager of an established business or involved in early-stage entrepreneurial activities in the U.S. As of 2008, women-owned businesses (defined as $50 \%$ or more women-owned) accounted for $40 \%$ of all privately-owned firms, generated $\$ 1.9$ trillion in sales and employed 13 million people. The SBA reported that high numbers of women want to become entrepreneurs and their ranks are growing at a rate six times faster than the number of self-employed men (Parker, 2010).

Also according to the World Bank report in the Middle East and North Africa Region in 2008, female-owned firms are as well established as male-owned firms. About $40 \%$ of female owned firms are individually owned, even if less than the $60 \%$ of male-owned firms. Female-owned firms are hiring more workers in general and also employ a higher share of female workers at professional and managerial levels and the workers are about as educated and as skilled as those in other firms. Male-owned firms employ more women in unskilled positions (Nabli and Chamlou, 2008).

Despite impressive growth in the number of firms run by women entrepreneurs, most of these businesses continue to remain small and women-owned firms have not grown as fast as those of their male counterparts have. They tend to be smaller, with less capital, have lower revenues and fewer employees, and reside in lower-profit industry services like handicrafts and textiles sectors. Also, their companies are more likely to be a sole proprietorship than a corporation (Buttner, 1993, Reshmi, 2002, Mooris, 2006, Brush and Gatewood, 2008, Roomi et al., 2009).

This difference in business growth is affected by various individual and environmental factors. Accessing different sources especially financial ones, different social networks, and various effects of socio-cultural environment on men and women in traditional countries like Iran makes the growth of the firms different. One of the factors that can affect growth is the growth orientation of the firm owner. Researchers have suggested a lower tendency towards growth among females, than male entrepreneurs; in other words, female entrepreneurs voluntarily decide not to have a high rate of growth in their business (Buttner, 1993, Verheul et al., 2005, Morris, 2006).

Considering the role of women in economy, studying the factors affecting growth orientation of women entrepreneurs in environmental aspects results a deeper attitude towards growth in women-owned businesses and may increase the development process in developing countries. Current study is supposed to identify the environmental factors which affect growth orientation of women entrepreneurs.

In this paper, first we focus on the literature review and the theoretical base of research. Then in two next sections, we will present the methodology of research and the result of qualitative study. Finally, paper will end with discussion and conclusion.

\section{Literature Review}

In this section, we review the literature on women's entrepreneurship studies about business growth and growth orientation.

\subsection{Women Entrepreneurs and Business Growth}

Growth in enterprises is a complex process and is multi-dimensional in scope and character where it is neither linear nor dependent on a limited number of factors (Roomi et al., 2009, Morrison, 2003). It embraces a convergence of owner-manager ambitions, intentions, and competencies, internal organizational factors, region specific resources and infrastructure, external relationships and network configurations (Morrison, 2003).

Many researchers have defined growth as "increase in sales revenue or the number of employees" (Gundry and Welsch, 2001, Reshmi, 2002, McGregor and Tweed, 2002, Mooris, 2006, Roomi, 2010).

Women view their businesses as an interconnected system of relationships in a social world, rather than as separate economic units. This system of relationships is integrated into the woman business owner's life. She is at the center of a network of relationships that include family, community and business (Brush, 1992).

Limited expansion of women-owned businesses might be further attributed to the fact that women have been less inclined than men to employ others, and have found it more difficult to obtain capital for growth (Reshmi, 2002). Result of research on Canadian women entrepreneurs shows that it can be because of lack of support, or other resources, or because of different growth intentions and motivations (Brown et al., 2001). Morrison (2003) recognized sets of factors that can affect growth of firms. They are demographic variables, personal characteristics, values and beliefs, educational level, knowledge of different fields of business, growth potential products, assets and premises, legal format of business, proactive learning through social, informal networks, market conditions, access to finance, public sector regulation, and labor market. McGregor and Tweed (2002) argued that business growth may be affected by factors such as lack of capital, family responsibilities, or by general, environmental factors rather than by the sole affect of entrepreneurial 
aspirations. Women entrepreneurs said that small and stable businesses were important to them. They wished to preserve their quality of life, to be customer and employee-focused, and to remain in control of the operational level of their businesses. Brush et al. (2006) believe that five theoretical perspectives explain growth of women-owned businesses: individual motivations and goals, social learning (entrepreneurial socialization), network affiliation (contacts and membership in organizations), human capital (level of education, business skills), and environmental influences (location, sectorial participation, and sociopolitical variables).

The situation in most Islamic countries is not the same as in the Western and other developed/developing countries. In most Islamic countries, socio-cultural variables play an important role in the growth of women owned enterprises. Women entrepreneurs do not enjoy the same opportunities as men due to a number of deep-rooted discriminatory socio-cultural values and traditions. Business family traditions, work experience in the same sector and independent mobility were some of the factors being important for the growth of enterprises (Roomi et al., 2010).

\subsection{Women Entrepreneurs and Growth Orientation}

Ylitalo (2010) indicates that growth orientation of management has a direct, positive and statistically significant effect on firm growth. There is a paradox in economic sciences and it is that, while most theories of company growth take the willingness to pursue growth for granted, empirical works, more often stress a widespread reluctance to growth. As an example, in a recent large-scale survey conducted by the Swedish Small Business Federation, 50\% of the managers who believe there is room for profitable expansion say they do not intend to exploit this opportunity (Davidsson, 1989). In other research on Iranian university educated women entrepreneurs, 80\% of women entrepreneurs choose none-growth strategies for their businesses and try to keep their businesses small (Arasti and Akbarijokar, 2009). On the contrary to popular beliefs, not all firms are willing to grow. In fact, in the majority of small and medium sized firms, growth orientation of management is not high, while management's desire to strive for growth is an important aspect of firm growth (Ylitalo, 2010). Kolvereid (1992) proposed that if the decision to start a business is a choice made by the founder, it may also be assumed that the decision to grow the business is a choice made by the entrepreneur.

Researchers often use several concepts as synonyms, which may make inferences vague, and comparison between studies more difficult. Several terms, such as growth aspiration, growth intention and willingness to grow, are commonly used interchangeably with growth orientation (Ylitalo, 2010).

Cliff(1998) defined propensity for growth as an entrepreneur's intent to expand the organization, and ability to manage growth as the degree to which he/she can obtain resources and develop the organization. Ylitalo (2010) and Morris (2006) have defined growth orientation as having growth as top priority, and accepting risk to achieve growth.

Economic factors: One of the factors that enhance or reduce the willingness of the entrepreneur to grow the business is conditions on the product market (Gundry and Welsch, 2001; Davidsson, 1989). Brush et al. (2006) investigated factors like lack of resources, environmental uncertainty, and lack of allocated financial resources which affect desire to grow of female entrepreneurs. Davidsson (1989) also expressed that the conditions on the financial market may affect the willingness to grow. Morris et al. (2006) investigated that "difficulty of getting investors", "difficulty of getting a commercial loan" and "difficulty of getting personal bank loans for business" are three items creating the greatest obstacles for women all related to financing. The other important factor explaining the desire for growth of women entrepreneurs is the presence of equity partners. The presence of other owners may indicate greater financial sophistication and a clear plan for organizational growth (Morris et al., 2006). Davidsson (1989) and Kolvereid (1992) have demonstrated that conditions on the labor market affected growth willingness. Availability and cost of labor are probably factors affecting growth aspirations. Kolvereid (1992) found that if labor is not available or affordable to the firm, one would not expect entrepreneurs to have strong employment growth aspirations.

Socio-cultural factors: Society and culture may play an important role in how women experience entrepreneurship. Sources of culture, behavioral norms, professional networks, and family relationships all affect the attitudes of women entrepreneurs (Morris, 2006). Kolvereid (1992) and Brush (2008) found that widespread reluctance to grow may be a cultural phenomenon. Morris et al. (2006) emphasizes on previous or current exposure to entrepreneurial or highly achieving role models, gender differences, limited access to networks and mentoring, conflicts between home and family demands as factors in growth orientation for many women entrepreneurs. Also, Cliff (1998) believes that female entrepreneurs may perceive that they have inadequate resources to pursue business growth. He point out that gender differences in entrepreneurs' growth intentions can partially be explained by differences in the resources available for business expansion and the value attached to growth. One of the resources available for expansion is defined as level of household responsibilities. The conflict between female entrepreneurs' professional and personal lives may be manifested in the adoption of reduced growth intentions. Morrison (2003) indicated that growth aspirations are related to external relationships and network configurations. 
Legal factors: Davidsson (1989) have demonstrated that external factors such as taxes and legislation affected growth willingness. Kolvereid (1992) investigated that the legislation in the Scandinavian countries is restrictive with regard to the owner-manager's right to lay off personnel. This legislation probably adds to the uncertainty involved in the growing of a business, and may explain the relatively high number of entrepreneurs who are concerned about productivity - for example growth without hiring additional employees. He also found that another feature of the Scandinavian countries is the lack of labor mobility.

Growth orientation, especially in small businesses represents a complex matter and is considered multidimensional, in scope and character. In this research based on Ylitalo (2010) definition, growth orientation was defined as having growth as top priority and accepting risk to achieve growth, and environmental factors are the combination of factors that play a role in the development of entrepreneurship. It refers to Gnyawali and Fogel's (1994) model that the overall economic, socio-cultural and political factors that affect people's willingness and ability to undertake entrepreneurial activities.

\section{Research Methodology}

In order to answer the research question and identify the environmental factors affecting women entrepreneurs' growth orientation, a qualitative study was done in a sample of women entrepreneurs, academic experts and decision makers in Tehran the capital city of Iran. The selection process was based on the following criterion:

- Academic experts in entrepreneurship especially in women's entrepreneurship

- Practitioners (women entrepreneurs in high-growth ventures)

- Active decision makers in the field of women's businesses

In total 10 semi-structured interviews with 1 decision makers, 1 academic expert and 8 women entrepreneurs were conducted between spring and summer 2011. Each interview takes in average 80 minutes. The decision maker who participated in interview was experienced in strategy making in fields of women. He was 39 years old with P.H.D degree. The academic expert who attended in interview was 35 years old and had P.H.D degree and her research field was about women entrepreneurs. Between women entrepreneurs who participated in interview, 6 people were active in service sector. Most of them ( 5 people) were over the age of 45 . The majority ( 5 people) had a master degree or higher. 4 people were in business for an average of 20 to 30 and 3 people were less than 10 years.

All Interviews were recorded and then transcribed for content analysis and conclusions. Content analysis is a research technique for making replicable and valid inferences from text or other meaningful matters, to the contexts of their use. As a research technique, content analysis provides new insights, increases the researcher's understanding of particular phenomena's, or informs practical actions (Krippendorff, 2004).

\section{Findings}

To conduct a content analysis on any such text, the text is coded or broken down into manageable categories on a variety of levels - word, word sense, phrase, sentence, or theme - and then examined using one of content analysis basic methods, either conceptual analysis, or relational analysis. All levels of content analysis have been presented in this section. First, the analysis of one interview as a sample is given in table 1. In this interview, eleven environmental factors affecting growth orientation of women entrepreneurs have been identified.

$<$ Table 1 about here>

In the first step, all factors identified from each interview are coded and have been presented in table 2 .

$<$ Table 2 about here $>$

There are many repetitive factors in 10 interviews. In the second step, all repetitions were omitted and the results are given in table 3 .

$<$ Table 3 about here $>$

In the last step, the factors presented in table 3 have been categorized in three groups based on their nature. The results are shown in table 4 .

$<$ Table 4 about here $>$

After content analysis on 10 interviews, all environmental factors affecting growth orientation of women entrepreneurs identified in three groups of economic, socio-cultural and legal factors. The final research model was presented in figure 1.

$<$ Figure 1 about here $>$ 


\section{Discussion}

Results of this qualitative study pointed out that growth orientation is a complex phenomenon. With regard to the finding, we can conclude that growth orientation is affected by "economic factors" includes conditions on the product market, conditions on the labor market, economic conditions and accessing to financial sources, "socio-cultural factors" includes cultural norms \& values, effects of social networks and work-home conflict and "legal factors" includes banking rules and regulations, tax laws and labor law.

Also the results of research presented that the influence of socio-cultural factors on growth orientation of women entrepreneurs is more than the other economic and legal factors.

Figure 1 resulted from our qualitative study show all environmental factors affecting growth orientation of women entrepreneurs in three levels. The detailed results are explained in three dimensions of economic, socio-cultural and legal factors as below:

\subsection{Economic Factors}

In this study, factors such as conditions on product market and labor market, access to financial sources have been identified as factors affecting the growth orientation of women entrepreneurs, and been approved in earlier studies includes Davidsson (1989), Morris et al. (2006), Kolvereid (1992), Brush et al. (2006), Gundry and Welsch (2001).

Of course, it is noteworthy that in past researches, there is no mention of concepts such as competitive pressure from other similar businesses, and the difficulty of attracting private investors; and these concepts have been extracted from our qualitative study.

In addition, in this study, economic conditions such as downturn and economic insecurity have been identified as factors that cause women to act as a prudent business owner, and less willing to express growth for the first time.

Women entrepreneurs stated that employing appropriate and skilled labor is more difficult for them than their men counterparts, and this is not only due to lack of adequate and trained work force in the market but also it is because of gender stereotypes - people are not so willing to work with woman managers.

\subsection{Socio-cultural Factors}

According to the results of this study, effects of social networks, cultural norms and values and work- home conflicts affect the growth orientation of women entrepreneurs. The impact of these factors have been identified and approved in earlier studies includes Morris et al. (2006), Cliff (1998), Kolvereid (1992), Morrison (2003), Brush et al. (2006).

Women try to make a balance between their responsibilities at home as well as at work. Despite the fact that family life was not considered to hinder the career development of women, family responsibilities are part of countries like Iran with religious and traditional beliefs, and women are continued to be viewed in this nurturing role. This may explain why more women work in the service sector as opposed to industry. Women because of many duties and responsibilities, face problems like time leakage, irritation and dissatisfaction which make them stress and pain. They experience greater family work conflict. Women entrepreneurs have reported that they come home from work too tired to engage in other desired activities. They stated that it is too difficult for them to be a complete mother, wife and manager. Therefore, they use special strategies to merge both business and family lives, managing both effectively and intentionally. So, they try to keep their business small; they know that they would have more conflicts if they grow their businesses.

In other hand, the importance of social relations is no secret; it plays an important role in growth of the firm, and entrepreneurs use their social capital to access opportunities, information and resources. In addition, social networks with providing an examples and role models and with support and motivation can affect the growth orientation of women entrepreneurs.

A challenge for many business owners lies in obtaining the appropriate assistance and information needed to take the business to the next level of growth. There are few organizations in Iran which provide information to women entrepreneurs. Therefore, they just rely on their family and friends' assistance. A striking result of this study is the positive effect of support and motivation of social networks on women entrepreneur's growth orientation. Most of them said that they use male supports.

Findings in the present study also indicate that presence of successful high growth businesses in their relatives and friends or knowing entrepreneurs in the society had an important role in women entrepreneurs' willingness to grow.

One of the consistent influences on female entrepreneurs' growth orientation throughout this study is the importance of cultural norms and values. Cultural norms and values have been identified as formal and informal culture. Formal culture is norms and rules, which are determined by the government and formal references like religion. Informal culture 
is the set of rules, which people have defined, like traditional rites, and behavioral norms and manners. Many female entrepreneurs report that they have to work harder than the men to prove their competence as business owners to customers, suppliers, and other resource providers. Actually stereotypes and gender-based discrimination can affect women's' economic activities directly or indirectly. Beliefs such as "women managers are not good for big capitals, women's mind is limited, women are emotional, and may leave their work because the family is their first priority, their husbands should be satisfied with their work to make women feel success and satisfaction", directly affects the growth orientation of women entrepreneurs. On the other hand, according to the results of this study, these values can also affect other factors like accessing financial capital, finding a business partner or investor, and recruiting appropriate personnel. In addition, values can make the process of obtaining loans more complicated, and this is because of the society's lack of confidence in women's ability.

\subsection{Legal Factors}

Based on the results of this research, legal factors affected the growth orientation of women entrepreneurs and have been classified in three groups: banking rules and regulations, tax laws, and labor law.

The impact of these factors have been identified and approved in earlier studies includes Morris et al. (2006), Cliff (1998), Kolvereid (1992), Morrison (2003), Brush et al. (2006).

Many researchers believe that access to financial resources is one of the important factors that affect growth orientation of business owners. In the absence of venture capital and angel investors, the importance of banking facilities as a way of providing capital for startup and growth will increase, because many women do not have enough personal assets to finance their work. In many cases they deal with many challenges to get loan from banks, because of complexity of the process of obtaining facilities, high interest rate and heavy collateral.

Another legal factor according to results of this study is the labor law. Women entrepreneurs agree that Iranian labor law is strict to the employers and do not permit them to fire the workers if they are not satisfied and this factor affect their willingness to growth.

Women entrepreneurs believe that tax incentives and tax rates can affect their growth orientation. According to the tax rules and regulations in Iran, tax exemptions and discounts include agricultural activities, education, service, sport, tourism and exports of goods and women are more active in these sectors.

\section{Conclusions}

To increase women involvement in the economic development of Iran, the government should target this group of women who have their own business, and have the potential to grow, but are deprived due to the lack of financial resources or social values, which prevents them from developing their own businesses. Based on the current study, it is possible to suggest priorities in terms of directions for future research. There is a need to develop models of growth orientation and it is the author's opinion that it is imperative to do with qualitative approaches. In addition, it is very important to focus on socio-cultural factors and identify them in depth, because it is clear that they have significant effects on the decision and behavior of women, particularly in Islamic and under developing countries. The relationship between growth propensity and ability to manage growth is another critical area requiring greater focus. None of the previous researches has focused on growth orientation of women entrepreneurs and the underlying reasons of inferior growth orientation in women compared to men.

This is a first study on growth orientation of women entrepreneurs that focus on environmental factors in detail by a qualitative research method. Accordingly, this qualitative data contributes to existing literature on growth orientation, but the limitations of largely interpretive, qualitative research make it problematic to generalize the results. This limitation will be tackled in a subsequent research phase of this project which is based on a large survey of women entrepreneurs. The items identified could also be incorporated to enhance a quantitative research in different contexts.

\section{References}

Arasti, Z. \& AkbariJokar M.R. (2009) Management Strategies and view of Iranian women entrepreneurs to success, Modares, 12(1), 56-77 (in Persian).

Brown, S. Doyle, W. Lewis, D. Mallette, H. Purcell, D. \& Young, J. (2001). Women Entrepreneurs in Canada in the 90s, Business Development Bank of Canada

Brush, C \& Gatewood, E. (2008). Women growing businesses: Clearing the hurdles, Business Horizons 51(3), 175-179, http://dx.doi.org/10.1016/j.bushor.2008.01.007 
Brush, c. (1992). Research on Women Business Owners: Past trends, A New Perspective and Future Directions. Entrepreneurship Theory and Practice. 16(4), 5-33.

Brush, C.G. Carter, N.M. \& Gatewood, E.J. (2006). Growth-oriented women Entrepreneurs and Their Businesses: A Global Research Perspective (New Horizons in Entrepreneurship Series). Edward Elgar Publishing LTD.

Buttner, E. (1993). Female Entrepreneurs: How far have they come?. Business Horizons, 36 (2), 59-65

Cliff, J. (1998). Does One Size Fit All? Exploring the Relationship between Attitudes towards Growth, Gender and Business Size, Journal of business Venturing, 13(6), 523-542, http://dx.doi.org/10.1016/S0883-9026(97)00071-2

Davidsson, P. (1989). Entrepreneurship and after? A Study of Growth Willingness in Small Firms, Journal of Business Venturing, 4(3), 211-226, http://dx.doi.org/10.1016/0883-9026(89)90022-0

Gnyawali, D. \& Fogel, D. (1994). Environments for Entrepreneurship Development: Key Dimensions and Research Implications. Entrepreneurship: Theory and Practice, 18(4), 43-62

Gundry, L. \& Welsch, H. (2001). The Ambitious entrepreneurship: High Growth Strategies of women- owned enterprises, Journal of business Venturing, 16(5), 453-470, http://dx.doi.org/10.1016/S0883-9026(99)00059-2

Kickul, J, Gundry, L. \& Sampson, D. (2007). Women entrepreneurship preparing for growth: the influence of social capital and training on resources Acquisition, Journal of Small Business and Entrepreneurship, 20(2), 169-182

Kolvereid, L. (1992). Growth Aspirations among Norwegian Entrepreneurs, Journal of business Venturing, 7(3), 209-222, http://dx.doi.org/10.1016/0883-9026(92)90027-O

McGregor, j. \& Tweed, D. (2002). Profiling a New Generation of Female Small Business Owners in New Zealand: Networking, Mentoring and Growth, Gender. Work and Organization, 9(4), 420-438, http://dx.doi.org/10.1111/1468-0432.00167

Morris, M.H., Miyasaki, N.N., Watters, C.E. \& Coombes, S.M. (2006). The Dilemma of Growth: Understanding Venture Size Choices of Women Entrepreneurs. Journal of Small Business Management, 44(2), 221-244, http://dx.doi.org/10.1111/j.1540-627X.2006.00165.x

Morrison, A , Breen, J \& Ali, Sh. (2003), Small Business Growth: Intention, Ability and Opportunity. Journal of Small Business Management. 41(4), 417-425, http://dx.doi.org/10.1111/1540-627X.00092

Nabli, M. \& Chamlou. N. (2008).The Environment for Women's Entrepreneurship in the Middle East and North Africa Region, Washington, D.C. World Bank report. http://dx.doi.org/10.1596/978-0-8213-7495-5

Parker, BJ. (2010). A Conceptual Framework for Developing the Female Entrepreneurship Literature. Journal of Research on Women and Gender, 1(2), 169-190

Reshmi, M. (2002). The Growth Pattern of Women-Run Enterprises: An Empirical Study in India. Journal of Developmental Entrepreneurship. 7(2), 217-237.

Roomi, M, Harrison, P. \& Beaumont-kerridge, J. (2009). Women-owned small and medium enterprises in England. Journal of Small Business and Enterprise Development. 16(2), 270-288, http://dx.doi.org/10.1108/14626000910956056.

Roomi, M. (2010). Entrepreneurial Capital, Social Values and Islamic Traditions: Growth of Women-Owned Enterprises in Pakistan. International Small Business Journal. (Accepted/Forthcoming)

Verheul, I , Stel, A. \& Thurik, R. (2006). Explaining female and male entrepreneurship at the country level. Entrepreneurship \& Regional development. 18(2), 151-183. http://dx.doi.org/10.1080/08985620500532053

Verheul, I. Uhlaner, L. \& Thurik, R. (2005). Business accomplishments, gender and entrepreneurial self-image. Journal of Business Venturing. 20 (4), 483-518, http://dx.doi.org/10.1016/j.jbusvent.2004.03.002

Ylitalo, J. (2010), Resources and growth orientation as predictors of firm growth, Master's thesis of Aalto University, Finland 
Table1. Verbal statement and derived components from a sample interview

\begin{tabular}{|c|c|c|}
\hline Interview & Components & Verbal statement \\
\hline \multirow{8}{*}{1} & $\begin{array}{l}\text { My father was so diligent, he was one } \\
\text { of my role models, and I decided to go } \\
\text { his way after his death. }\end{array}$ & $\begin{array}{c}\text { Provide an example and } \\
\text { role model }\end{array}$ \\
\hline & $\begin{array}{l}\text { It is too difficult to find investors; the } \\
\text { society does not trust women yet, so I } \\
\text { inevitably keep my business small. }\end{array}$ & $\begin{array}{l}\text { Difficulty of getting } \\
\text { investors }\end{array}$ \\
\hline & $\begin{array}{l}\text { Finding an equity partner is very } \\
\text { difficult for females. Men and women } \\
\text { have different opinions; quality is more } \\
\text { important for women. }\end{array}$ & $\begin{array}{l}\text { Difficulty of getting } \\
\text { business partners }\end{array}$ \\
\hline & $\begin{array}{l}\text { Business is currently sluggish and } \\
\text { stagnant. In this situation even men } \\
\text { don't risk. The economic situation is } \\
\text { unstable, so I act cautiously and do not } \\
\text { start new projects. }\end{array}$ & $\begin{array}{c}\text { Downturn } \\
\text { Economic insecurity }\end{array}$ \\
\hline & $\begin{array}{l}\text { Many still think that women are less } \\
\text { able than men are, their mind is } \\
\text { limited, and they have lower power } \\
\text { analysis, so they do not rely on women } \\
\text { entrepreneurs to invest on their } \\
\text { business. }\end{array}$ & $\begin{array}{l}\text { Gender stereotypes } \\
\text { Distrust the ability of } \\
\text { women } \\
\text { Difficulty of getting } \\
\text { investors }\end{array}$ \\
\hline & $\begin{array}{l}\text { The process of obtaining bank loans is } \\
\text { very complex and boring, so some } \\
\text { times I give up. I think it is more } \\
\text { difficult for women because they think } \\
\text { that women are not good managers for } \\
\text { large capitals, they believe that they } \\
\text { cannot tolerate the difficulties of work, } \\
\text { so they act stricter. }\end{array}$ & $\begin{array}{l}\text { Complex loan } \\
\text { Obtaining Process } \\
\text { Distrust the ability of } \\
\text { women }\end{array}$ \\
\hline & $\begin{array}{c}\text { The Interest rate of banking facilities is } \\
\text { so high that it simply is not } \\
\text { economical. }\end{array}$ & $\begin{array}{l}\text { High interest rate of } \\
\text { banking facilities }\end{array}$ \\
\hline & $\begin{array}{l}\text { I am afraid of paying more taxes. I } \\
\text { always think that why should I try to } \\
\text { earn more income when I have to pay a } \\
\text { high percentage of my high income as } \\
\text { tax? }\end{array}$ & High tax rates \\
\hline
\end{tabular}


Table2. Extracted concepts for each interview

\begin{tabular}{|c|c|}
\hline Interview No. & Concept \\
\hline 1 & $\begin{array}{l}\text { 1. Difficulty of getting business partner } \\
\text { 2. High product demand } \\
\text { 3. labor lay off laws } \\
\text { 4. High labor costs } \\
\text { 5. Provide an examples and role models } \\
\text { 6. Gender stereotypes } \\
\text { 7. Religious beliefs } \\
\text { 8. Support and motivation effect of social networks } \\
\text { 9. Physical pressures }\end{array}$ \\
\hline 2 & $\begin{array}{l}\text { 10. Economic insecurity } \\
\text { 11. Gender stereotypes } \\
\text { 12. Difficulty of getting business partner } \\
\text { 13. Difficulty of getting investors } \\
\text { 14. High tax rates } \\
\text { 15. Provide an examples and role models } \\
\text { 16. Complex Loan Obtaining Process } \\
\text { 17. High interest rate of banking facilities }\end{array}$ \\
\hline 3 & $\begin{array}{l}\text { 18. Gender stereotypes } \\
\text { 19. Psychological pressures } \\
\text { 20. Physical pressures } \\
\text { 21. High labor costs } \\
\text { 22. Provide an examples and role models } \\
\text { 23. High product demand } \\
\text { 24. High interest rate of banking facilities }\end{array}$ \\
\hline 4 & $\begin{array}{l}\text { 25. Difficulty of getting investors } \\
\text { 26. Distrust the ability of women } \\
\text { 27. Dissatisfaction of family } \\
\text { 28. Provide an examples and role models } \\
\text { 29. Assistance in accessing to opportunities, information and resources } \\
\text { 30. Competitive pressure from other similar businesses } \\
\text { 31. Complex Loan Obtaining Process }\end{array}$ \\
\hline 5 & $\begin{array}{l}\text { 32. Labor mobility laws } \\
\text { 33. Distrust the ability of women } \\
\text { 34. Difficulty of getting investors } \\
\text { 35. Support and motivation effect } \\
\text { 36. Expert opinion and counseling effect } \\
\text { 37. High labor costs } \\
\text { 38. Tax Incentives } \\
\text { 39. Provide an examples and role models } \\
\text { 40. Heavy Collateral }\end{array}$ \\
\hline 6 & $\begin{array}{c}\text { 41. High product demand } \\
\text { 42. Gender stereotypes } \\
\text { 43. Lack of appropriate Labor } \\
\text { 44. Religious beliefs } \\
\text { 45. Complex Loan Obtaining Process } \\
\text { 46. Heavy Collateral } \\
\text { 47. Provide an examples and role models }\end{array}$ \\
\hline 7 & $\begin{array}{l}\text { 48. Religious beliefs } \\
\text { 49. High labor costs } \\
\text { 50. Competitive pressure from other similar businesses } \\
\text { 51. High interest rate of banking facilities } \\
\text { 52. Support and motivation effect of social networks }\end{array}$ \\
\hline
\end{tabular}




\begin{tabular}{|c|c|}
\hline & 53. Distrust the ability of women \\
\hline 8 & $\begin{array}{l}\text { 54. Expert opinion and counseling effect } \\
\text { 55. Dissatisfaction of family } \\
\text { 56. Physical pressures } \\
\text { 57. Psychological pressures } \\
\text { 58. Lack of appropriate Labor } \\
\text { 59. Religious beliefs } \\
\text { 60. labor lay off laws } \\
\text { 61. Distrust the ability of women }\end{array}$ \\
\hline 9 & $\begin{array}{l}\text { 62. Lack of appropriate Labor } \\
\text { 63. Economic insecurity } \\
\text { 64. Distrust the ability of women } \\
\text { 65. Provide an examples and role models } \\
\text { 66. High product demand } \\
\text { 67. High tax rates }\end{array}$ \\
\hline 10 & $\begin{array}{l}\text { 68. High product demand } \\
\text { 69. Provide an examples and role models } \\
\text { 70. Assistance in accessing to opportunities, information and resources } \\
\text { 71. Downturn } \\
\text { 72. Labor mobility laws } \\
\text { 73. Economic insecurity } \\
\text { 74. Distrust the ability of women }\end{array}$ \\
\hline
\end{tabular}

Table3. Extracted components

\begin{tabular}{|c|l|l|}
\hline No. & \multicolumn{1}{|c|}{ Extracted component } & \multicolumn{1}{c|}{ Coding } \\
\hline 1 & Conditions on the product market & $2-23-30-41-50-66-68$ \\
\hline 2 & Conditions on the labor market & $4-21-37-43-49-58-62$ \\
\hline 3 & Accessing to financial sources & $1-12-13-25-34$ \\
\hline 4 & Economic condition & $10-63-71-73$ \\
\hline 5 & Social networks & $5-8-15-22-28-29-35-36-39-47-52-54-65-69-70$ \\
\hline 6 & Cultural norms \& values & $6-7-11-18-26-33-42-44-48-53-59-61-64-74$ \\
\hline 7 & Work-home conflict & $9-19-20-27-55-56-57$ \\
\hline 8 & Banking rules \& regulations & $16-18-24-31-40-46-45-51$ \\
\hline 9 & Tax law & $14-38-67$ \\
\hline 10 & Labor law & $3-32-60-72$ \\
\hline & &
\end{tabular}

Table4. Extracted dimensions

\begin{tabular}{|c|l|l|}
\hline No. & \multicolumn{1}{|c|}{$\begin{array}{c}\text { Extracted } \\
\text { dimension }\end{array}$} & Coding \\
\hline 1 & $\begin{array}{l}\text { Economic } \\
\text { factors }\end{array}$ & $1-2-4-10-12-13-21-25-23-30-34-37-41-43-49-50-58-62-63-66-68-71-73$ \\
\hline 2 & $\begin{array}{l}\text { Socio-cultural } \\
\text { factors }\end{array}$ & $5-6-7-8-9-11-15-18-19-20-22-26-27-28-29-33-35-36-39-42-44-47-48-52-53-54-55-56-57-59-61-64-65-69-70-74$ \\
\hline 3 & Legal factors & $\begin{array}{l}14-16-18-24-31-32-40-46-45-51 \\
14-38-60-67-72\end{array}$ \\
\hline
\end{tabular}




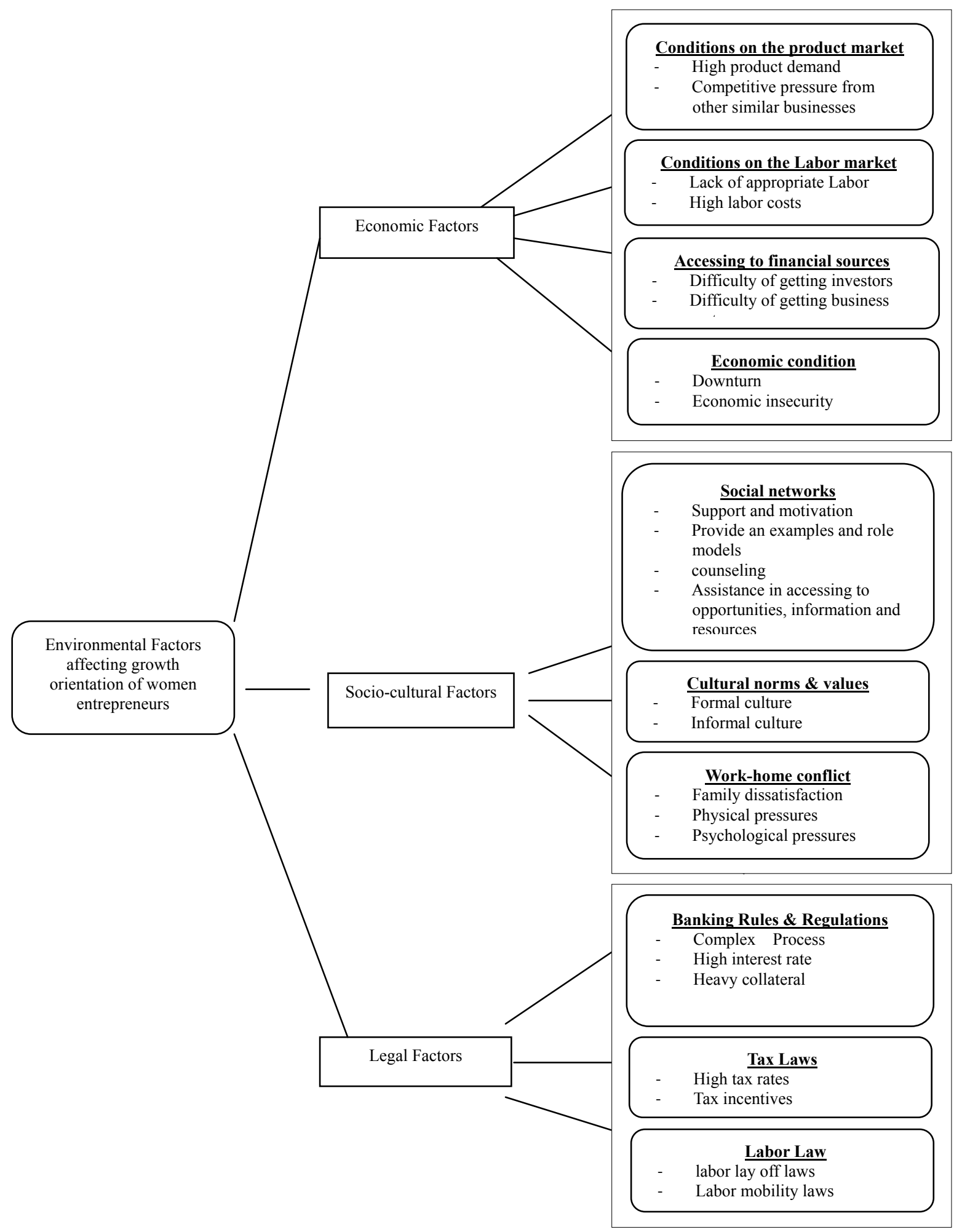

Figure1. Environmental factors affecting growth orientation of women entrepreneurs 